\title{
How to Develop Chinese Flower Auction Markets: Results from a Comparative Analysis
}

\author{
Kaida Qin, Xiaoli Jiang, Baojian Yang \\ College of Management and Economics, Kunming University of Science \& Technology, Kunming, China. \\ E-mail: kdqin2005@yahoo.com,JXL198@126.com,YBJ1366@kmust.edu.cn
}

Received August 24 $4^{\text {th }}, 2010$; revised October 11 ${ }^{\text {th }}, 2010$; accepted November $21^{\text {st }}, 2010$.

\begin{abstract}
For the vast majority of floriculture business, the auction is the best way to realize an assortment of flowers with as broad a scope as possible, produced across the world, and available for market price. FloraHolland is the largest and successful flower auction market in the world and approximately 44 million cut flowers and 4.8 million houseplants and garden plants are traded daily. But the operation of Chinese flower auction markets is not so successful that some researchers have concluded that the auction method doesn't suit to Chinese practice. This paper compares operational goals and performances of FloraHolland with Kunming, International Flower Auction Market (KIFA), which are two typical flower auction markets in the two countries. Finally, the paper gives five crucial advices for developing Chinese flower auction markets: transit of service strategies, cultivation of participants' network, establishing standardization, clever mechanism design and avoiding some factors impairing successful auction, and improving on operational performance continuously. Auction method will have a bright perspective in Chinese flowers trade in the future.
\end{abstract}

Keywords: Operations Strategy, Chinese Flower Auction Markets, Auctions

\section{Introduction}

At present, the main transaction mode in China is competitor deal. Higher transaction costs and lower efficiency, insufficient market information and unjust transaction price are competitor deal's main weakness, which restrict the development of agricultural circulation and agricultural industrialization. Compared with competitor deal mode, the auction market can result in significant savings for both sellers and buyers. Savings are made by reducing transaction costs, increasing the circle of potential customers as well as by improving the search-andfind capabilities for all members concerned [1]. Electronic auctioning in particular is a rapidly expanding application [2]. The additional benefit of the auction is the matching of demand and supply at the 'best price' at one specific point in time. The advantages, however, must be weighed up against lower switching costs for auction participants [3]. And with these good reasons, for the vast majority of floriculture business the auction is the World Trade Center: a better way to realize an assortment of flowers with as broad a scope as possible, produced across the world, and available for market price

The paper is supported by the provincial application foundation of Yunnan under grant 2009ZC019M reflecting the supply and demand in a short time. The auction provides a hugely diverse selection of trade companies with equally diverse quantities of flowers and plants.

The Netherlands is the international crossroads for commercial trade in flowers and plants. As the largest producers of flowers, plants and tree nursery products, the Netherlands processes more than fifty percent of the international trade. On 1 Jan. 2008, Bloemenveiling Aalsmeer and the former FloraHolland merged into one company, under the name FloraHolland. FloraHolland is the largest and successful flower auction in the world, through which approximately 44 million cut flowers and 4.8 million houseplants and garden plants are traded daily. FloraHolland is market leader and key player in the international floriculture sector.

China is one of the biggest countries for production and sales in flowers and plants. Yunnan is the largest center of greenhouse horticulture in china and provides more than fifty percent of the domestic production for China. In Yunnan province there are approximately 16000 growers and almost 6000 wholesales companies and exporters [4,5]. Kunming International Flower Auction Market (KIFA) is the only normally operational flower auction market in China, through which each day 
approximately 1.2 million cut flowers are sold to domestic and international market. For KIFA, Nov. 2007 was a month full of positive developments with new operational process, inner logistics and information system of the organization, which resulted in transaction capacity from 300 thousands to 4000 thousands daily. The KIFA continues to invest in strengthening the markets and increasing gains in efficiencies throughout the chain of production, supply and sales.

However, some researchers have concluded that the auction doesn't suit to Chinese fresh agricultural product's trade because of unsuccessful operation. In despite of improving on operational performance, there are still huge gaps between FloralHolland and KIFA. In this paper we compare operational goals and performance of FloraHolland with KIFA, which are two typical flower auction markets in two countries. We also analyze some reasons for those gaps between these two auction markets. Finally, some crucial factors are presented for developing Chinese flower auction market in the future.

The remainder of this article is structured as follows: First we briefly review the related literature on flower auction. Section 3 compares operational goals of FloraHolland with KIFA and analyzes some reasons for these gaps. In Section 4, we compare key figures 2007 of FloraHolland with 2008 of KIFA and analyze the differences of operational performances between two auction markets. In Section 5, we give five operational strategy's emphasis for developing Chinese flower markets. Section 6 ends with conclusions and implications for research and practice.

\section{Literature Review on Flower Auction}

Prior research abroad on developing flower auction typically emphasized on its function and transaction price. Heezen and Baets [6] discussed functions of the Dutch Flower Auction on the view of organizational structure. More researches on flower auction have discussed price discovery mechanisms. A central argument of these articles was that flower auction would improve communication searches, monitoring and information-sorting capabilities, reduce transaction costs and allow purchasers to take advantage of production economics available in markets. Bakos [7] argued that auction marketplaces could reduce the search costs that buyers must incur to acquire information about seller prices and product offerings. The lowered search costs allow buyers to look at more product offerings and make it difficult for sellers to sustain high prices. Koppius et al. [3] compared screen auctioning and physical auction. They reckoned that screen auctioning entailed a decrease in information about flower quality compared to the physical product representation and might be a partial explanation for re- duced prices in electronic markets.

A central argument of Chinese research was considering adaptability of implementing agricultural product auction method in China from the macroeconomic perspective. Zhu Xin-Kai [8] considered that the auction method doesn't suit to Chinese practice in terms of government malfunction, market mechanism faultiness and lower-level agency institution. Kou Ping-Jun and Lu Feng-Jun [9] argued that it must be careful to put agricultural product auction methods in practice because of some limitations of social condition and history. Li Da-Sheng and Zhang Guang-Hui [10] discussed some technical economic issues about agricultural product auction and characterized that auction method was the direction about reform and development of agricultural product currency systems. However, it is the fact that almost all of Chinese fresh agricultural product auction markets had bad financial position over the past years. KIFA was the same status before Nov. 2007. After then new business model, which was designed by Qin Kai-Da, Yang Bao-Jian and et al., was successfully introduced into KIFA. In this paper, however, we emphasize on how to develop Chinese flower auction markets through comparative analysis.

\section{Operational Goals' Comparison and Analysis}

Having operated for over a hundred years, FloraHolland has developed a mature vision and mission: In a market that is characterized by upscaling and internationalization, FlorHolland wants to maintain and increase its strong market position. By offering the best and broadest assortment, it wishes to tie (international) commerce flows to the marketplaces. In addition, it offers its members the best sales opportunities at lowest possible costs. Begin with the vision and mission, FloraHolland formulates its operational goals. KIFA, established in 2002, got a great success after the introduction of FloraHolland's operational mode. But there are great differences in organizational goals between them, as shown in Subsection 3.1.

\subsection{Operational Goals' Comparison}

According to FloraHolland, it divides objectives and ambitions into seven indexes: best pricing at lowest possible costs, growth of supply, broadening product range, optimal logistical services, e-business, sound financial position and limiting labor costs where possible. For best pricing at lowest possible costs, the market needs to continuously decrease transaction costs and offer added value for membership. Strengthening supply network will improve control capacity to market, which is called growth of supply. Another issue is to help suppliers to find market for new product and help buyers conven- 
iently to buy all of products at the same market, it needs broadening product range. All of products may distribute to all of world, so optimal logistics service is very important. In the information age, e-business can make buyers and growers trade their products more efficiently at a lower cost. The operational performance is the premise for auction market existing, so sound financial position and limiting labor costs where possible is crucial to market. Table 1 shows differences between FloraHolland and KIFA for objectives and ambitions in 2009.

From this table we can find that there exist huge gaps between two markets. Some macro-economic environments and policies, such as market mechanisms, traditional trade methods, social conditions, and et al., may result in these gaps. But we give more emphasis on the differences of organizational operation model. Subsection 3.2 analyzes these gaps.

\subsection{Analysis of Operational Goals' Gaps}

Operational goals' gaps may root in the following:

1) Organization structure. FloraHolland is a cooperative composed of approximately 5400 growers. This means it is not an intermediary with independent interests. All activities in FloraHolland are to promote its members' products. Therefore, the goals designed from the members' interest are norm and fair. The structure has proven to guarantee a stable, broad and international supply as well as ensure the best pricing process. In the contrast, the stockholders of KIFA are from third-party investors. What it considers first is the commission. By continually updating, fostering and re-engineering auction method, KIFA has begun to become a crucial hub for buyers, suppliers and logistic stakeholders in China.
2) Transaction service. FloraHolland can provide different transaction services: selling at clock, sales through FloraHolland Connect (image auctioning and remote buying), cooperative sales, and direct sales. Selling at clock and sales through FloraHolland connect is main dealing mode in trade, although some growers' groups find the right price using FloraHolland Connect's services in their direct sales. The limitation of clock auction is that the selling price is very volatile, considering different lots of the same producer or different lots of different producers [3]. In KIFA it can only deal with clock transaction, and at present it has provided 'best price' at lowest possible costs for both buyers and growers in China.

3) Electronic information systems and e-business. Buyers and growers may more efficiently and conveniently trade their products at FloraHolland. Using the internet, growers up to one hundred percent of the supply and buyers all over the world may purchase their products at one of FloraHolland's 39 auction clocks. But now KIFA's information systems only meet the needs of clock transaction. Buyers must be physically present in the auction hall.

4) Stability and reliability of supply. Keeping growers loyal to the cooperative is an important aim of FloraHolland. It commits supply to the cooperative through value adding services for members at rates and under terms that are more favorable for members than for nonmembers. A growing part of and Product \& Market Services (PMD) and FloraHolland Connect's services is custom advice. Large-scale production is another way to ensure the steady supply. Moreover, the flowers auctioned in FloraHoolland are not only limited to products

Table 1. Objectives and ambitions in 2009.

\begin{tabular}{|c|c|c|}
\hline Issue & FloraHolland's Goals & KIFA's Goals \\
\hline $\begin{array}{l}\text { Best pricing at lowest } \\
\text { possible costs }\end{array}$ & $\begin{array}{l}\text { Offer added value for membership. Reliable information on } \\
\text { product quality: increasing BI (Reliability Index). }\end{array}$ & $\begin{array}{l}\text { Competitive pricing and rates above average } \\
\text { appeal to buyers and suppliers. }\end{array}$ \\
\hline Growth of supply & $\begin{array}{l}\text { More than } 95 \% \text { of Dutch product sold through FloraHolland. } \\
\text { Growth in supply of import flowers equal to or greater than } \\
\text { growth in production of flowers outside the Netherlands. }\end{array}$ & $\begin{array}{l}\text { Improving batch size to } 180 \text { units. More than } \\
80 \% \text { of some categories sold through KIFA. } \\
\text { Growth in turnover exceeds } 10 \% \text { at least. }\end{array}$ \\
\hline Broadening product range & $\begin{array}{l}\text { Virtually all new flower and plant varieties introduced in } \\
\text { Europe available at FloraHolland within } 6 \text { months. }\end{array}$ & $\begin{array}{l}\text { Strengthening patent categories management. } \\
\text { Inducing new categories. }\end{array}$ \\
\hline Optimal logistical services & $\begin{array}{l}\text { Chain standardization through uniform auction trolley, } 1 \\
\text { Danish trolley balance, financial settlement, standardized } \\
\text { delivery form. }\end{array}$ & $\begin{array}{l}\text { Building collecting center in main planting } \\
\text { area, decreasing supplier's logistics costs. }\end{array}$ \\
\hline E-business & $\begin{array}{l}\text { EAB to } 100 \% \text { of supply. Further development of virtual } \\
\text { marketplace. MyFloraHolland.com to be made broader and } \\
\text { deeper. Further develop reliable product information. }\end{array}$ & $\begin{array}{l}\text { Every supplier and buyer can get their detail } \\
\text { transaction information through internet. The } \\
\text { public can get transaction information in gen- } \\
\text { eral. }\end{array}$ \\
\hline Sound financial position & $\begin{array}{l}\text { Pre-tax result of } € 10 \text { million. Solvency at least } 20 \% \text { and } \\
\text { risk-bearing equity at least } 40 \% \text { of balance sheet total. }\end{array}$ & $\begin{array}{l}\text { Commission result of } ¥ 35 \text { million. Solvency } \\
\text { ten percent of the total balance. }\end{array}$ \\
\hline $\begin{array}{l}\text { Limit labor costs where } \\
\text { possible }\end{array}$ & $\begin{array}{l}\text { Illness-related absence down (5.2\%). Personnel reduction of } \\
90 \text { FTEs in } 3 \text { years. }\end{array}$ & $\begin{array}{l}\text { The improvement of total labor costs doesn't } \\
\text { exceed } 10 \% \text {. }\end{array}$ \\
\hline
\end{tabular}


in Netherlands but also from Israel, Kenya, Colombia and etc. Whereas in KIFA, the flowers sold are mainly supplied by local growers. And growers can freely choose their dealing location and method, for example, many growers trade their products at Dounan Flower Market in wholesale method. In addition, small-scale production results in periodic intermittent supply.

5) Destination of sale. FloraHolland wants to maintain and reinforce FloraHolland's position as the marketplace for European flower sales, maintaining its central position in the world's leading areas for greenhouse horticulture is also its long development strategy. KIFA is one of biggest trade center in China, its buyers are almost from all of Chinese inner large-medium-scale cities. A small quantity of buyers is from Hongkong. Russia and Thailand sometimes take part in auction.

6) Logistics systems. FloraHolland has already established integrated systems for logistics, including inner logistical systems, logistical resources, and international logistical support. RFID, uniformed trolley resource, cool chain, potted-plant distribution, and air freight is being developed for supply and distribution chain from farm to auction market and from auction market to distribution at FloraHolland. Due to the restriction of external environments, KIFA now applies itself to establish collecting center in main planting area to decrease supplier's logistics costs due to scale economies and re-design internal logistics distribution mode to improve allocation efficiency.

7) Standardization. The decoding standards of varieties, products, grades, and qualities have been built for many years at FloraHolland. After merged in Jan. 2008, it will more rapidly achieve standardization in the whole chain of production and supply. FloraHolland have decided that all the trolleys, all the purchase and sales invoicing will be carried out the same standard for various locations and FloraHolland connect. Owing to standard scarcity of agricultural production in China, KIFA is now hammering at own intellectual property right of cut flowers.

\section{Operational Performances' Comparison and Analysis}

Because 2008 was the first year of operating in new business model for KIFA and we can just get figures 2007 of FloraHolland, this paper use FloraHolland's figures 2007 and KIFA's figures 2008 for operational performances' comparison. In fact, key figures 2008 for FloraHolland are almost the same as 2007 except for operational result. Due to revenue being approximately the same, an increase of charges, and extra costs for merging, the operational result of FloraHolland decrease by $50.5 \%$.

\subsection{Comparison and Analysis of Basic Indexes}

The past two years were turbulent because of financial crisis. Although sales of flowers and plants were generally not very sensitive to economic recessions, growth market shrank as a result of currency problems. FloraHolland is also striving to support its clients and members do business optimally in the current difficult circumstances. The number of suppliers and traders of FloraHolland did not grow in 2007. Turnover increased by $4.4 \%$. This resulted in a total turnover of $€ 3,892$ million. The increase can be attributed to a $3.8 \%$ positive price trend and an increase in volume of $1 \%$ (see Table 2). Commission revenue just increased $0.4 \%$, as a result of a reduced commission for the auction clock. The scale of suppliers and traders for FloraHolland has improved. These may be private companies and cooperative ventures, which operated as a major player in the market and were well placed to innovate. Number of employees of FloraHolland in 2007 deceased by $0.46 \%$, at the same time, the productivity had $2.5 \%$ increase which ensured the volume increase.

The year 2008 for China is a significant one because Peking Olympic Games was successfully held in Peking. So KIFA predicted sales, price and supply of cut flowers would have increased rapidly. But in fact sales, price and supply of cut flowers in China did not grow in 2008. Despite the difficult economic situation, 2008 ended with a hugely positive turnover for KIFA because of new business model. Annual turnover of KIFA increased by $53 \%$, it resulted in a total of $¥ 163$ million. The increase can be owed to an increase in volume $60 \%$. Commission revenue increased by $53 \%$, it resulted in a total of $¥ 16.4$ million, which it is the first time that the revenue exceed the general costs (see Table 2). The number of suppliers and trades increased by $16 \%$ and $20 \%$ individually, as a result of the best price, the reliable quality, the decreased costs, the sufficient information and the increasing service level. The average number of transactions per day increased by $62 \%$ and the number of employees increased by $31 \%$, it resulted in $60 \%$ increase in productivity in KIFA. 2008 was crucial and successful done one for KIFA, including operationally, commercially and financially.

However, lack of trading location (only 1 location) is a limitation to increasing the product supply. Considering the product category, it is difficult for KIFA to meet the buyers' requirement by auctioning certain kinds of cut flowers while the products sold in FloraHolland cover almost all types of flowers and pot plants. The commission fee is also a noteworthy point. The commission rate in KIFA is $10.11 \%$ out of annual turnover, $8.65 \%$ greater than the commission rate in FloraHolland. 
Table 2. Comparision of basic indexes between floraholland and kifa.

\begin{tabular}{|c|c|c|c|c|}
\hline \multirow{2}{*}{ Item } & \multicolumn{2}{|c|}{ FloraHolland's figures } & \multicolumn{2}{|c|}{ KIFA's figures } \\
\hline & 2007 & Growth & 2008 & Growth \\
\hline Num. of locations & 6 & - & 1 & - \\
\hline Num. of auction halls & 12 & - & 1 & - \\
\hline Num. of Auction Clocks & 39 & - & 3 & - \\
\hline Num. of suppliers & 9,633 & $-4.23 \%$ & 5,290 & $15.91 \%$ \\
\hline Num. of traders(buyers) & 5,600 & $-0.69 \%$ & 785 & $19.85 \%$ \\
\hline Num. of employees & 4,593 & $-0.46 \%$ & 127 & $30.93 \%$ \\
\hline Num. of processed trolleys & $8,163,819$ & - & 355,979 & - \\
\hline Avg. num. of transactions pd & 115,982 & $0.74 \%$ & 6,322 & $62.25 \%$ \\
\hline Annual turnover & $€ 3,892,377,734$ & $4.40 \%$ & $¥ 162,567,764$ & $52.82 \%$ \\
\hline Commission fee & $€ 56,800,000$ & $0.40 \%$ & $¥ 16,473,225$ & $52.99 \%$ \\
\hline
\end{tabular}

Such a high commission is one of the factors that buyers and suppliers won't choose the auction as their transaction mode.

\subsection{Comparison and Analysis of Key Figures}

The sales of floriculture products for FloraHolland were a great success in 2007. Cut flowers, indoor plants and outdoor plants increased $1.74 \%, 8.78 \%$ and $9.54 \%$ individually (see Table 3). Exports from the Netherlands grew by $4.4 \%$, thanks to the growth in Eastern Europe, France, the United Kingdom and Ireland. One attentive trend in FloraHolland is that sales through by connect had a great increase by $11.4 \%$. Remote buying (RB) has grown enormously in the past few years. Deals do not only buy in the auction room but also via an internet connection which means the location can be anywhere in the world. Another important fact is that the price of outdoor plants and indoor plants sold by connection is higher than by auction, which is different fact with the conclusion of Koppius et al. (2004). From Table 3, we can also see that the revenue of selling indoor plants and outdoor plants is very large, about $38.5 \%$ out of total turnover. That means it is profitable not only through cut flower sales but also through indoor plants and outdoor plants sales.

Although the sales of cut flowers for KIFA were a great increase in 2008, an important trend is that the ratio of bidding failure is increased. KIFA views this phenomenon in a positive sight. It means that the lower quality and outdated product should be washed out from the market. But on the other hand, it will depress the confidence of Chinese growers. Another difficulty for KIFA is that the batch size of cut flowers is also small at 180 units, at the same time, FloraHolland at 1800 units. Improving batch size of growers is a long-term and difficult task.

\section{Operations Strategies for Developing Chinese Flower Auction Markets}

Although auction is an old-fashioned deal method, it remains a strong selling instrument in foreign countries. Now FloraHolland is striving to intermediary services in direct transactions via the intermediary organization FloraHolland connect. But in China auction method emerged among some regions just in recent ten years, the cultivation of auction thought is a long-term process for growers and buyers. Most of fresh agricultural auction markets in China were shutdown in past few years due to lower revenue. Through the comparison of operational goals and performances, we conclude that five operational strategy's emphasis for developing Chinese flower auction markets as follows:

1) Transit of service strategies. Changing service thought is an important factor of Chinese flower auction markets. First of all, the auction market is not only the location for providing auction transaction, but an integral service provider for transaction, balance, logistics, information and direct sales. Second, providing customized service is crucial to keep participants loyal, so measures must be taken to decrease participants' transaction costs to guarantee that growers and buyers choose auction as public platform for trade, such as providing various trade mode (including remote buying or bidding, direct sales, and agent sales), excellent logistics and online payment. Finally, the auction market must be the knowledge center for participants. It can provide information on services and the very latest products, trends and sales concepts, so it can help participants to make their decisions.

2) Cultivation of participants' network. Constructing participants' network is a long-term and difficult process. The auction market must seek to achieve the highest pos- 
Table 3. Floraholland's key figures 2007 and kifa's key figures 2008.

\begin{tabular}{|c|c|c|c|c|c|}
\hline Item & Revenue & Revenue pd & Units & Units pd & Avg. Price \\
\hline \multicolumn{6}{|l|}{ FloraHolland 2007} \\
\hline Total Turnover & $€ 4,063,495,188$ & $€ 16,253,981$ & - & - & - \\
\hline Cut flowers & $€ 2,497,112,508$ & $€ 9,988,450$ & $11,005,090,382$ & $44,020,362$ & $€ 0.2269$ \\
\hline Indoor plants & $€ 1,268,720,500$ & $€ 5,074,882$ & $831,800,074$ & $3,327,200$ & $€ 1.5253$ \\
\hline Outdoor plants & $€ 297,662,180$ & $€ 1,190,649$ & $391,328,824$ & $1,565,315$ & $€ 0.7606$ \\
\hline \multicolumn{6}{|l|}{ Sold via } \\
\hline Cut flowers & $€ 2,497,112,508$ & $€ 9,988,450$ & $11,005,090,382$ & $44,020,362$ & $€ 0.2269$ \\
\hline Auction clocks & $€ 2,140,565,953$ & $€ 8,562,264$ & $9,375,452,681$ & $37,501,811$ & $€ 0.2283$ \\
\hline Connect(mediation) & $€ 356,544,685$ & $€ 1,426,179$ & $1,629,637,701$ & $6,518,551$ & $€ 0.2188$ \\
\hline Indoor plants & $€ 1,268,720,500$ & $€ 5,074,882$ & $831,800,074$ & $3,327,200$ & $€ 1.5253$ \\
\hline Auction clocks & $€ 444,185,187$ & $€ 1,776,741$ & $390,232,402$ & $1,560,930$ & $€ 1.1383$ \\
\hline Connect(mediation) & $€ 824,535,313$ & $€ 3,298,141$ & $441,567,672$ & $1,766,271$ & $€ 1.8673$ \\
\hline Outdoor plants & $€ 297,662,180$ & $€ 1,190,649$ & $391,328,824$ & $1,565,315$ & $€ 0.7606$ \\
\hline Auction clocks & $€ 123,803,638$ & $€ 495,215$ & $208,774,931$ & 835,100 & $€ 0.5930$ \\
\hline Connect(mediation) & $€ 173,858,542$ & $€ 695,434$ & $182,553,893$ & 730,216 & $€ 0.9524$ \\
\hline KIFA 2008 & $¥ 162,567,764$ & $¥ 461,840$ & $333,826,689$ & 948,371 & $¥ 0.487$ \\
\hline
\end{tabular}

sible price at the lowest possible expense for all members. The participants' network is the best important assets for all of auction markets. As a result, it is very important to provide convenience, laborsaving, and happiness services for all members. An obvious trend is a growth in large scale flower and plant nurseries in China because of scale economies. The increases in scale take place predominantly through acquisition. The market may stimulate this and endeavor to increase the return because it is helpful to extend participants' network.

3) Establishing standardization. Compared to traditional firsthand market, the auction market can provide uniform quality standard. Product quality is a high priority for auction market. The auction organization would offer the opportunity to more rapidly achieve standardization in the chain of production and supply. Doing this could greatly decrease the intermediate links and improve trading efficiency. The standards of varieties, products, grades, and qualities are the first of all for Chinese auction market, which is the basis for well-doing operation. Owing to scarcity of fresh agricultural product standard, establishing standard is a difficult task for Chinese auction markets.

4) Clever mechanism design and avoiding some factors influencing successful auction. Clever mechanism designs are only very occasionally among the main keys to an auction's success. Much more often, the keys are to keep the costs of bidding low, encourage the right participants to participate, and ensure the integrity of the process. Some other factors are more important for Chinese auction market, such as setting right reservation price and commission rate, building clever disposal mechanism for lodge and bidding failure, and developing agent organizations for the small-medium growers and buyers.

5) Improving on operational performance continuously. Our experiences in auction practice teach that the well financial result is crucial to auction organizations. The measurements must be brought into auction organization's eyes, such as saving general costs for auction market, improving work efficiency, turnover, and service level, and increasing revenue and value added service. All these measurements require technology innovation continuously. Remote supply, remote buying, image auctioning, online sales systems, and direct sales, all of these new business models should be put into use through technology innovation.

\section{Conclusions}

The paper presents operation strategies for developing Chinese flower auction markets through the comparison FloraHolland with KIFA. Since November 2007, it has led to the enormous change for KIFA's revenue. Despite the proclaimed huge potential of auction markets for Chinese fresh agricultural circulation in the future and controversy with regards to whether auction method suits to Chinese practice, little is known about how to develop Chinese flower auction markets. We contributed to this debate by comparing two auction markets. Chinese flower auction organizations must pay more attentions to its operational performance, not just concern about macro economic environments and policies. They will find that auction method will have a bright perspective in Chinese flower's trade in the 
future.

\section{Acknowledgements}

The authors gratefully acknowledge cooperation from Kunming International Flower Auction Market (KIFA).

\section{REFERENCES}

[1] A. Kambil and E. van Heck, "Re-Engineering the Dutch Flower Auctions: A Framework for Analyzing Exchange Organizations," Information Systems Research, Vol. 9, No. 1, March 1998, pp. 1-19.

[2] S. Klein, "Introduction to Electronic Auctions," International Journal of Electronic Markets, Vol. 7, No. 4, December 1997, pp. 3-6.

[3] O. R. Koppius, E. V. Heck and M. J. J. Wolters, “The Importance of Product Representation Online: Empirical Results and Implications for Electronic Markets," Decision Support Systems, Vol. 38, No. 2, November 2004, pp. 161-169.

[4] K.-D. Qin and B.-J. Yang, "Implementation of Information Platform for Fresh Flower Supply Chain-Survey from Kunming International Flower Auction Market," Proceedings of International Conference on Industry Cluster Development and Management, July 2008, pp.
595-599.

[5] K.-D. Qin and B.-J. Yang, "The Storage Assignment Policy under Uncertainty: Case of Kunming International Flower Auction," Proceedings of 2008 International Conference of Production and Operation Management (ICPOM'08), December 2008.

[6] J. Heezen and W. Baets, "The Impact of Electronic Markets: The Case of the Dutch Flowe Auction," Journal of Strategic Information System, Vol. 5, No. 2, Decemeber 1996, pp. 317-333.

[7] J. Y. Bakos, "A Strategic Analysis of Electronic Marketplaces," MIS Quarterly, Vol. 15, No. 3, September 1991, pp. 295-310.

[8] X.-K. Zhu, "The Thinking about Chinese Agriculture Product Dealing Method," Economic Issues, No. 3, March 2005, pp. 48-50. (in Chinese)

[9] P.-J. Kou and F.-J. Lu, "The Adaptability Analysis of Implementing Agricultural Product Auction Method in China," Chinese agricultural Economy, No. 8, 2003, pp. 18-23. (in Chinese)

[10] D.-S. Li and G.-H. Zhang, "The Discussion of Some Technical Economic Issues about Agricultural Product Auction," Agricultural Technical Economy, No. 1, 2003, pp. 31-34. (in Chinese) 